\title{
FASILITAS DAN SISTEM KOMPENSASI DAMPAKNYA PADA KINERJA KARYAWAN DI BANK BJB SYARIAH KCP. KUNINGAN
}

\author{
Regi Destanti Apriyani ${ }^{1}$, Biki Zulfikri Rahmat ${ }^{2}$, Agus Ahmad Nasrulloh ${ }^{3 *}$ \\ ${ }^{1}$ Program Studi Ekonomi Syariah, Universitas Siliwangi, regidestantiapriyani@gmail.com \\ ${ }^{2}$ Program Studi Ekonomi Syariah, Universitas Siliwangi, bikizulfikrirahmat@unsil.ac.id \\ ${ }^{3}$ Program Studi Ekonomi Syariah, Universitas Siliwangi, agusahmad@unsil.ac.id
}

\begin{abstract}
Good employee performance will be achieved if you pay attention to what factors can influence it. The case that occurred at Bank BJB Syariah KCP Kuningan was that employees complained about work facilities and the compensation system. The method used in this study is a descriptive method with a qualitative approach. With two data sources, namely primary data sources consisting of leaders and all employees at Bank BJB Syariah KCP. Brass and secondary data sources consisting of documents both in writing and photos at Bank BJB Syariah KCP. Brass. Data collection techniques used are interviews, observation and documentation. The research instrument is the researcher himself as the main instrument in the research, observation guide and interview guide. The results showed that the facilities provided by Bank BJB KCP. Kuningan is inadequate, the internet network is often disturbed, the lack of operational vehicles, the parking area is not large enough, thus disrupting employee performance. As for compensation, the institution has given it fairly and fairly well in accordance with existing regulations. Both of these things certainly have an impact on employee performance, so that it can be said that the failure of the BJB Syariah Bank, Kuningan Sub-Branch Office, has not been able to meet the needs to improve employee performance.
\end{abstract}

Keywords: facilities, compensation system, employee performance

\begin{abstract}
ABSTRAK
Karyawan akan memiliki kinerja baik jika memperhatikan faktor-faktor yang dapat mempengaruhinya. Fenomena di Bank BJB Syariah KCP Kuningan disebabkan adanya keluhan dari karyawan mengenai fasilitas kerja dan sistem pembayaran. Metode deskriptif dengan pendekatan kualitatif menjadi metode yang dipakai dalam penelitian ini. Sumber data yang digunakan berasal dari pejabat dan seluruh pegawai Bank BJB Syariah KCP. Kuningan dan sumber data sekunder meliputi catatan tertulis dan foto dari Bank BJB Syariah KCP. Kuningan, dan teknik wawancara, observasi serta dokumentasi dipakai dalam pengumpulan data. Peneliti sebagai alat penelitian utama dalam pedoman penelitian, pedoman observasi dan pedoman wawancara. Hasil Pencarian menunjukkan bahwa pada Fasilitas yang disediakan oleh Bank BJB KCP. Kuningan ada yang kurang memadai, jaringan internet yang sering mengalami gangguan, kurangnya kendaraan operasional, lahan parker yang kurang luas, sehingga mengganggu kinerja
\end{abstract}


karyawan. Sedangkan untuk kompensasi, pihak lembaga sudah memberikan secara adil dan cukup baik sesuai dengan peraturan yang ada. Kedua hal tersebut tentunya memberikan dampak pada kinerja karyawan, sehingga dapat dikatan untuk failitas pihak Bank BJB Syariah KCP. Kuningan belum bisa memenuhi kebutuhan untuk meningkatkan kinerja para karyawan.

Kata Kunci: fasilitas, sistem kompensasi, kinerja karyawan

\section{PENDAHULUAN}

Perusahaan mengharapkan staf karyawan yang profesional dan mempunyai kinerja yang tinggi. Secara keseluruhan, produktivitas perusahaan akan meningkat jika kinerja karyawannya semakin baik, sehingga secara global perusahaan mampu bertahan dalam persaingan. Kinerja yang sangat tinggi serta profesionalitas pada karyawan tentunya sangat dihadapkan oleh perusahaan. Kemampuan bertahan dalam persaingan yang dimiliki oleh perusahaan akan tercapai jika produktivitas perusahaan meningkat yang diakibatkan oleh kinerja karyawannya semakin baik.

Menurut Sutrisno (2009), pada prinsipnya kompensasi adalah :

hasil penjualan sumber daya manusia kepada perusahaan untuk meningkatkan prestasi kerja, motivasi, kepuasan kerja dan segala sesuatu yang diterima karyawan sebagai kompensasi atas hasil kerjanya. Namun dalam hal ini juga berarti bahwa karyawan telah mencurahkan seluruh potensinya kepada perusahaan, oleh karena itu perusahaan harus menghargai kerja keras karyawan dalam memberikan kompensasi yang sesuai kepada karyawannya.

Permasalahan yang terjadi di bank syariah mengenai kompensasi yaitu keterlambatan pemberian kompensasi kepada karyawan. Skala kehidupan ekonomi karyawan ditentukan oleh tingkat kompensasi, sedangkan kompensasi itu sendiri cenderung menunjukan status dan harga karyawan. Oleh karena itu, jika karyawan memandang bahwa kompensasi dan fasilitas tidak memadai maka produktifitas, prestasi kerja serta kepuasan kerja karyawan akan turun.

Berdasarkan hasil observasi peneliti, di lapangan terdapat beberapa masalah yang dialami para karyawan di Bank BJB Syariah KCP. Kuningan. Terdapat beberapa karyawan yang mengalami masalah mengenai kelengkapan fasilitas kerja karena kurang lengkapnya fasilitas yang disediakan oleh Bank BJB Syariah KCP. Kuningan seperti kurang luasnya lahan parkir yang disediakan oleh perusahaan, ruangan karyawan yang sempit, tidak lengkapnnya peralatan kantor, akibatnya menghambat kinerja para karyawan. Selain itu ada juga masalah dalam 
pemberian kompensasi terhadap karyawan yang terkadang terjadi keterlambatan, dan memberikan dampak pada karyawan menjadi tidak semangat dalam mengerjakan tugasnya serta ada beberapa pekerjaan atau tugas yang terhambat dan tertunda karena fasilitas yang kurang memadai.

Hal lain yang ditemukan dalam pengamatan awal yang dilakukan kepada beberapa karyawan di Bank BJB Syariah KCP. Kuningan, bahwa karyawan menyatakan adanya masalah mengenai pemberian kompensasi yang terlambat, pemberian upah hari libur serta upah kerja malam yang tidak sesuai dengan kinerja karyawan. Adapun karyawan yang menyatakan bahwa fasilitas di Bank BJB Syariah KCP Kuningan kurang lengkap sehingga dapat menghambat kinerja para karyawan.

Kondisi di atas bertentangan dengan teori, karena secara teori kinerja karyawan sangat menentukan keberhasilan suatu usaha. Prestasi kerja karyawan yang baik akan berbanding lurus dengan hasil yang baik, dan sebaliknya prestasi kerja yang buruk juga akan berdampak negatif terhadap bisnis. Untuk menciptakan karyawan yang berkinerja tinggi, perusahaan harus selalu memperhatikan factor apa saja yang dapat mempengaruhi kinerja karyawan.

Menurut Mangkunegara (2009), faktor yang dapat memberikan pengaruh pada kinerja yaitu faktor internal dan eksternal: "Faktor internal yaitu faktor yang dihubungkan dengan sifatsifat seseorang. Sedangkan faktor eksternal adalah fakror-faktor yang mempengaruhi kinerja seseorang yang berasal dari lingkungan. Seperti prilaku, sikap, dan tindakan-tindakan rekan kerja, bawahan atau pimpinan, fasilitas kerja, kompensasi dan iklim organisasi."

Berdasarkan hasil penelitian Anis Lutfia (2015) menyatakan bahwa fasilitas, gaji serta insentif mempunyai pengaruh pada produktivitas kinerja karyawan. Hasil penlitian lain adalah dari penelitian Selda Audina, Kurniati dan Teguh Wicaksono (2020), menyatakan bahwa sistem kompensasi yang diterapkan belum berjalan efektif dan tidak memberikan berpengaruh terhadap kinerja karyawan. Selain itu, Muhamad Nizam (2018) juga melakukan penelitian yang hasilnya menyatakan bahwa kompensasi dapat memberikan pengaruh pada kinerja karyawan.

Kondisi yang terjadi di Bank BJB.Syariah KCP. Kuningan, tentunya dipengaruhi oleh banyak faktor, akan tetapi peneliti menduga terdapat dua faktor paling signifikan memberikan pengaruh terhadap kinerja pegawai BJB Syariah KCP. Kuningan, yaitu pertama faktor fasilitas. Faktor ini termasuk dalam faktor sistem yang dapat menunjang kinerja pegawai, namun pada kenyataannya pada pengamatan awal sebanyak pegawai merasa fasilitas kantor cabang BJB 
Syariah Kuningan belum lengkap. Akibatnya, dapat mengganggu tugas-tugas yang harus segera dilakukan.

Faktor kedua adalah unsur kompensasi yang diterima oleh karyawan sebagai imbalan atas pekerjaan yang dilaksanakan oleh karyawan, dan secara teoripun ada faktor-faktor yang mempengaruhi kinerja karyawan. Namun kenyataan menunjukkan bahwa kompensasi, liburan, dan upah malam hari masih mengalami keterlambatan yang tidak sesuai dengan kinerja pekerja. Dengan adanya permasalahan tersebut, peneliti berpendapat bahwa perlu dilakukan survei untuk menganalisis kinerja pegawai terkait fasilitas dan skema kompensasi.

\section{LITERATUR REVIEW}

\section{Pengertian Fasilitas}

Menurut Moekijat (2001), fasilitas adalah

suatu sarana fisik yang dapat memproses suatu masukan (input) dan keluaran (output) yang diinginkan. Fasilitas adalah sarana untuk melancarkan dan memudahkan pelaksanaan fungsi. Fasilitas juga diartikan sebagai kemudahan dan dapat diartikan sebagai alat atau bentuk fisik (sarana atau prasarana). Sedangkan menuurut Handani (2006), fasilitas adalah sarana untuk melancarkan dan memudahkan pelaksanaan fungsi. Fasilitas merupakan komponen individual dari penawaran yang mudah dutumbuhkan atau dikurangi tanpa mengubah kualitas dan model jasa. Fasilitas juga merupakan alat untuk membedakan program lembaga pendidikan yang satu dari pesaing lainnya.

Definisi dari Fasilitas kerja adalah

Sarana pendukung dalam aktifitas perusahaan bentuk fisik dan digunakan dalam kegiatan normal perusahaan, memiliki jangka waktu kegunaan yang relatif permanen dan memberikan manfaat untuk masa yang akan datang (Danim, 1995).

Menurut beberapa sumber di atas, penulis menyimpulkan bahwa fasilitas adalah alat atau infrastruktur yang disediakan perusahaan yang membantu karyawan melakukan setiap tugas dengan lebih mudah dan menciptakan tugas yang lebih produktif.

\section{Jenis Fasilitas}

Sofyan (2001) menjelaskan tentang berbagai jenis fasilitas kerja, diantaranya :

Mesin dan peralatannya, prasarana, perlengkapan kantor, peralatan inventaris, tanah, bangunan, alat transportasi, fasilitas kesehatan.

\section{Indikator Fasilitas}

Terdapat lima indikator dalam fasilitas, diantararanya: 
Pertama: Sarana dan prasarana,merupakan alat penunjang keberhasilan suatu proses upaya yang dilakukan di dalam pelayanan publik, karena apabila kedua hal ini tidak tersedia maka semua kegiatan yang dilakukan tidak akan dapat mencapai hasil yang diharapkan sesuai dengan rencana; Kedua: Jaminan kesehatan: Jaminan kesehatan merupakan jaminan pelindungan terhadap keselamatan kerja para karyawan disuatu organisasi. Ketiga: Insentif yaitu imbalan diansial langsung yang diberikan kepada karyawan berlandaskan jam kerja, jumlah barang yang dihasilkan atau banyaknya pelayanan yang diberikan; Keempat: Kompensasi, merupakan sesuatu yang diterima karyawan sebagaai pengganti konstribusi jasa mereka pada perusahaan atu organisasi; Kelima: Jenjang karir, yaitu jalur yang dilalui suatu karir ketika karyawan mencapai kemajuan ke posisi dengan tanggung jawab lebih besar.

\section{Fasilitas Menurut Pandangan Islam}

Fasilitas menurut pandangan Islam terdapat pada Q.S An Nahl ayat 81, yang berbunyi:

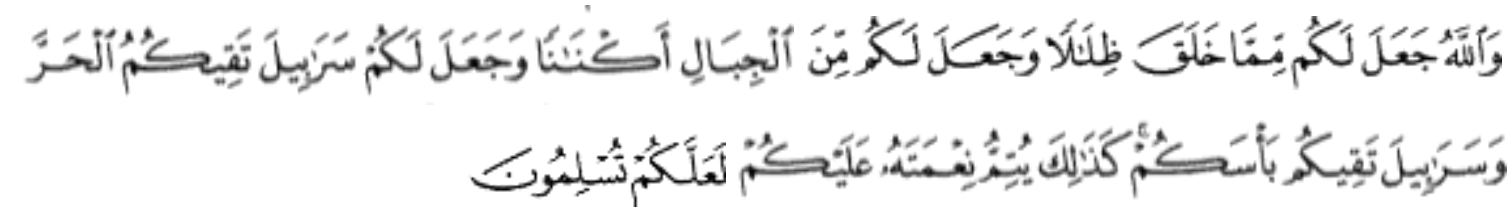

Artinnya: dan dari apa yang ia ciptakan, ia membuat tempat berlindung bagi kamu dan ia membuat gunung sebagai tempat pengungsian bagi kamu dan ia memberi pakaian kepada kamu untuk melindungi kamu dari panas dan baju rantai untuk melindungi kamu dalam pertempuran. Demikianlah ia menyempurnakan nikmat-Nya kepada kamu agar kamu tunduk (kepada-Nya). (Q.S An-Nisa [4] : 81)

\section{Kompensasi}

\section{Pengertian Kompensasi}

Menurut Marihot T.E Hariandja dalam Sulastri (2010), menyatakan bahwa

"kompensasi adalah keseluruhan balas jasa yang diterima pegawai sebagai akibat dari pelaksanaan pekerjaan di organisasi dalam bentuk uang atau lainnya yang dapat berupa gaji, upah, bonus, insentif dan tunjangan lainnya seperti tunjangan kesehatan, tunjangan hari raya, uang makan, uang cuti dan lain-lain. Programprogram kompensasi juga penting bagi perisahaan, karena mencerminkan upaya organisasi untuk mempertahankan sumber daya manusia. Disamping itu kompensasi (dalam bentuk pengupahan dan balas jasa lainnya) sering merupakan komponenkomponen biaya yang paling besar dan penting."

Melayu S.P Hasibuan menyatakan bahwa :

"kompensasi adalah semua pendapatan yang berbentuk uang, barang langsung maupun tidak langsung yang diterima karyawan sebaggai imbalan atas jasa yang diberikan kepada perusahaan. Kompensasi yang berbentuk uang artinnya kompensasi yang dibayar dengan sejumlah uang kartal bagi karyawan yaang bersangkutan, sedangkan 
kompensasi berbentuk barang artinya kompensasi yang dibayar dengan barang, misalnya kompensasi dibayar $10 \%$ dari produksi yang dihasilkan.”

Menurut beberapa sumber diatas penulis menyimpulkan bahwa kompensasi adalah imbalan yang diberikan oleh perusahaan kepada karyawan, yang saling membutuhkan satu sama lain, baik berupa kompensasi yang langsung maupun yang tidak langsung. Kompensasi yang diberikan perusahaan biasannya berbentuk uang maupun barang. Terdapat dua pihak yang memiliki tanggung jawab yang berbeda, akan tetapi dapat saling memberikan pengaruh dan menentukan. Pihak kesatu yaitu adalah karyawan, yang mempuyai tanggung jawab kepada perusahaan untuk mengerjakan kegiatan atau tugas yang diberikan oleh perusahaan. Sedangkan pihak kedua adalah perusahaan, yang mempunyai tanggung jawab untuk memberikan penghargaan kepada karyawan berupa kompensasi.

\section{Jenis Kompensasi}

Kompensasi dikelompokan menjadi dua, yaitu :

Pertama : kompensasi langsung (direct compensation), dan kedua adalah kompensasi tidak langsung (indirect compensation). Kompensasi langsung adalah kompensasi yang secara langsung diterima oleh pegawai atau karyawan, seperti upah dasar (basic pay), Upah kinerja (merit pay=pay for performance), Upah insentif (insentive pay), dan upah yang ditunda. Sedangkan kompensasi tidak langsung yaitu pembayaran finansial dan nonfinansial yang diterima tenaga kerja sebagai tambahan kompensasi langsung yang mereka terima, seperti program proteksi, upah ketika tidak bekerja, dan Services dan prerequisite.

\section{Tujuan Kompensasi}

Kompensasi memiliki tujuan membantu organisasi untuk mencapai keberhasilan yang strategis, dan memastikan adanya keadilan baik internal maupun eksternal. Keadilan internal atau internal equity memastikan bahwa posisi yang lebih menantang atau orang yang lebih berkualitas dalam perusahaan dibayar lebih baik. Pada saat yang sama, ekuitas eksternal memastikan bahwa pekerjaan mendapat upah yang adil dibandingkan dengan pekerjaan serupa di pasar tenaga kerja.

\section{Fungsi Kompensasi}

Efektivitas dan efisiensi perusahaan merupakan tujuan yang hendak dicapai dari adanya kompensasi. Selain itu, kompensasi juga memiliki fungsi-fungsi, yaitu:

Pertama : Sistem kompensasi atau adannya kompensasi dalam sebuah perusahaan dapat menjadi perangkat pemberdayaan sumber daya manusia agar lebih efektif dan kreatif dalam bekerja; kedua:Kompensasi dapat berfungsi sebagai perangkat untuk menjaga 
stabilitas perusahaan; ketiga: Kompensasi dapat berfungsi sebagai perangkat untuk meningkatkan pertumbuhan ekonomi dan finansial sebuah perusahaan (Sulastri, 2010).

\section{Indikator Kompensasi}

Menurut Singodimedjo dalam Sutrisno (2009), indikator dari kompensasi untuk dapat mengukur kinerja karyawan pada suatu organisasi atau perusahaan secara individu, yaitu:

Pertama : Gaji, yaitu kompensasi uang diberikan kepada seorang karyawan secara periodik (sebulan sekali); kedua : Tunjangan, adalah kompensasi yang diberikan perusahaan kepada para karyawannnya, karena karyawan tersebut dianggap telah ikut berfartisipasi dengan baik dalam mencapai tujuan sebuah perusahaan. Contohnnya, tunjangan jabatan, keluarga, trasport, perumahan dan lain sebagainnya. Ketiga: Insentif atau bonus, yaitu kompensasi yang diberikan kepada karyawan tertentu, karena keberhasilan prestasi atas prestasinnya; lima: Fasilitas, yaitu kompensasi berupa penyediaan fasilitas yang biasanya tidak berdiri sendiri, tetapi sekaligus sebagai tambahan dari bentuk kompensasi uang atau materi.

\section{Kompensasi Menurut Pandangan Islam}

Kompensasi menurut pandangan Islam terdapat pada Q.S At-Taubah ayat 105, yang berbunyi:

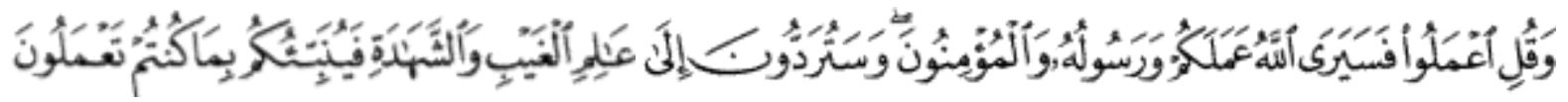

Artinya: Dan katakanlah: "Bekerjalah kamu, maka Allah dan Rasul-Nya serta orangorang mukmin akan melihat pekerjaanmu itu, dan kamu akan dikembalikan kepada (Allah) yang mengetahui akan yang ghaib dan yang nyata, lalu diberitahukan-Nya kepada kamu apa yang telah kamu kerjakan." (Q.S At-Taubah [9]: 105) .

\section{Kinerja Karyawan}

\section{Definisi Kinerja}

Kinerja menurut Sulastri (2016) adalah :

"hasil yang diperoleh oleh suatu organisasi baik organisasi tersebut bersifat profit oriented dan non profit oriented yang dihasilkan selama satu periode waktu. Menurut Amstrong dan Baron mengatakan bahwa kinerja adalah hasil pekerjaan yang mempunyai hubungan kuat dengan tujuan strategis organisasi, kepuasan konsumen dan memberikan konstribusi ekonomi.(Sulastri, 2016).

Sedangkan menurut Michael Armstrong adalah

"Performance management can be defined as a systematic process for improving organizational performance of individual and teams." (Kinerja dapat didefinisikan sebagai suatu proses yang sistematis untuk meningkatkan kinerja organisasi dengan mengembangkan kinerja individu dan tim (Lubis, 2018). 
Menurut beberapa sumber diatas penulis menyimpulkan bahwa kinerja karyawan adalah hasil pekerjaan yang memiliki hubungan dengan tujuan sebuah perusahaan, serta berkaitan dengan kepuasan konsumen dan memberikan konstribusi ekonomi terhadap semua aspek.

Menurut beberapa sumber di atas, penulis menyimpulkan bahwa kinerja karyawan merupakan yang dihasilkan dari pekerjaan terkait dengan tujuan organisasi atau bisnis, dan terkait dengan kepuasan pelanggan dan berkontribusi pada semua aspek.

\section{Faktor-faktor yang Mempengaruhi Kinerja}

Tingkat kinerja suatu organisasi sangat tergantung pada kinerja karyawannya dan kualitas manajer yang ada. Manajer bertanggung jawab untuk memastikan bahwa pekerjaan di unitnya dapat diselesaikan dalam waktu yang wajar dengan biaya yang sesuai. Banyak masalah yang menghambat pekerjaan terkait dengan masalah manajer.Menurut Handoko (2001), faktorfaktor yang dapat mempengaruhi kinerja, yaitu:

Pertama: Motivasi, merupakan faktor pendorong yang paling penting, yang menyebabkan manusia bekerja adalah adannya kebutuhan yang harus dipenuhi; Kedua : Kepuasan kerja, mencerminkan perasaan seseorang terhadap pekerjaannya. Hal ini terlihat dari sikap positif karyawan terhadap pekerjaan dan segala sesuatu yang dihadapi dilingkungan kerjannya; Ketiga: Tingkat stress, merupakan suatu kondisi ketegangan yang mempengaruhi emosi, proses berpikir dan kondisi sekarang; Keempat: Fasilitas, Kondisi pekerjaan yang dimaksud dapat mempengaruhi kinerja disini adalah tempat kerja, ventilasi, serta penyinaran dalam ruangan kerja; Kelima: Sistem kompensasi, merupakan tingkat balas jasa yang diterima oleh karyawan atas apa yang telah dilakukan untuk perusahaan; Keenam: Desain pekerjaan , merupakan fungsi penetapan kegiatankegiatan kerja seseorang individu atau kelompok karyawan secara organisasional.

\section{Indikator Kinerja Karyawan}

Menurut kasmir (2016), indikator untuk mengukur kinerja karyawan secara individu, yaitu:

Pertama : Kualitas. Kualitas kerja diukur dari presepsi karyawan terhadap kualitas pekerjaan yang dihasilkan serta kesempurnaan tugas terhadap keterampilan dan kemampuan karyawan; Kedua : Kuantitas, merupakan jumlah yang dihasilkan dinyatakan dalam istilah seperti jumlah unit, jumlah siklus aktivitas yang diselesaikan; Ketiga : Ketepatan waktu, merupakan tingkat aktivitas yang diselesaikan pad awal waktu yang dinyatakan, dilihat dari sudut koordinasi dengan hasil output serta memaksimalkan waktu yang tersedia untuk aktivitas lain; Keempat: Efektivitas, merupakan tingkat penggunaan sumber daya organisasi (tenaga, uang, teknologi, bahan baku) dimaksimalkan dengan maksud menaikan hasil dari setiap unit dalam penggunaan sumber daya; Kelima : Kemandirian, merupakan tingkat seseorang karyawan yang nantinnya akan dapat menjalankan fungsi kerjannya. Komitmen kerja dengan instansi dan tanggung jawab karyawan terhadap kantor atau perusahaan; Keenam : Komitmen. Karyawan yang 
berkomitmen cenderung akan lebih termotivasi dan memiliki rasa bertanggung jawab untuk mengerjakan pekerjaan dengan lebih baik.

\section{Kinerja Karyawan Menurut Pandangan Islam}

Kompensasi menurut pandangan islam terdapat pada Q.S Al Ahqaaf ayat 19, yang berbunyi:

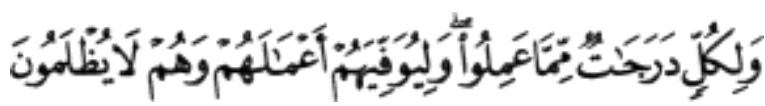

Artinya: dan semua orang mempunyai derajat yang selaras dengan apa yang mereka lakukan dan agar mereka membayar penuh segala perbuatan mereka dan mereka tak akan diperlakukan tak-adil. (Q.S Al-Ahqaaf [26] : 19).

\section{METODE}

Metode penelitian ini menggunakan metode kualitatif, yang tujuannya untuk mengetahui bagaimana fasilitas dan sistem kompensasi dalam meningkatkan kinerja karyawan di Bank BJB. Syariah KCP. Kuningan. Sumber data yang digunakan adalah sumber data primer merupakan Pimpinan dan perwakilan karyawan dari setiap jabatan di Bank BJB Syariah KCP. Kuningan yang terdiri dari laki-laki empat orang dan perempuan tiga orang menjadi data primer dalam penelitian ini. Sedangkan data sekundernya adalah berupa dokumen baik secara tertulis maupun foto di Bank BJB Syariah KCP. Kuningan.

Teknik yang dipakai dalam pengumpulan data pada penelitian ini yaitu observasi secara terus terang kepada sumber data, wawancara langsung kepada sumber data yaitu pimpinan serta karyawan BJB Syariah KCP. Kuningan. Dokumentasi yang digunakan adalah foto, catatan saat melakukan wawancara dengan responden. Peneliti dijadikan sebagai instrument penelitian, dan instrument lainnya adalah pedoman wawancara.

Berdasarkan pada kriteria derajat kepercayaan, pemeriksaan keabsahan data penelitian menggunakan teknik perpanjangan keikutsertaan, kekuatan pengamatan dan triangulasi. Sedangkan, teknik analisis data menggunakan Model Miles dan Huberman.

\section{HASIL DAN PEMBAHASAN}

Analisis Fasilitas dan Sistem Kompensasi dalam Meningkatkan Kinerja Karyawan di Bank BJB. Syariah KCP. Kuningan.

\section{a. Fasilitas}




\section{Sarana dan Prasarana}

Fasilitas yang sangat mendukung kinerja karyawan di BJB Syariah KCP Kuningan mengenai sarana dan prasarana seperti alat tulis, peralatan kantor, ruangan sudah cukup lengkap. Akan tetapi ada beberapa keluhan yang dirasakan karyawan yaitu akses jaringan internet yang sering mengalami gangguan, lahan parkir yang kurang luas dan kurangnya inventaris kendaraan seperti mobil sehingga menghambat konerja karyawaran tertama pada bagian Marketing Funding Officer dan Marketing Account Officer.

\section{Jaminan Kesehatan}

Menurut Pimpinan BJB Syariah KCP. Kuningan, pemberian jaminan kesehatan diberikan secara merata kepada seluruh karyawan Bank BJB Syariah Kantor Cabang Pembantu Kuningan hanya saja nominalnya yang berbeda-beda disesuaikan dengan jabatan yang diterima. Adapun manfaat yang dirasakan karyawan Bank BJB Syariah Kantor Cabang Pembantu Kuningan dengan adanya jaminan kesehatan. Dengan adannya jaminan kesehatan para karyawan merasa lebih nyaman, aman dan tenang dalam mengerjakan pekerjaan mereka, sehingga para karyawan dapat menjalankan tugasnya dengan baik.

\section{Insentif}

Mengenai pemberian Insentif, imbalan dan kompensasi di Bank BJB Syariah KCP. Kuningan diberikan ketika karyawan memiliki prestasi dalam pekerjaannya, seperti mencapai target perusahaan contohnya mencapai target dalam pembukaan rekening, menjalankan tugasnnya dengan baik. Insentif, imbalan dan kompensasi ditetapkan atau diberikan sesuai dengan jam kerja, pencapaian para karyawan dan banyaknya pelayanan yang diberikan oleh karyawan.

\section{Kompensasi}

Proses pemberian kompensasi di Bank BJB. Syariah KCP. Kuningan biasanya diberikan ketika akhir bulan, nominal kompensasi yang diberikan sesuai dengan jam lembur karyawan, perhitungannya Rp. 50.000/jam

\section{Jenjang Karir}

Jenjang karir di Bank BJB Syariah Kantor Cabang Pembantu Kuningan yang terbuka luas, dengan adanya jenjang karir membuat para karyawan lebih termotivasi dalam bekerja, para karyawan di Bank BJB Syariah Kantor Cabang Pembantu Kuningan bisa meningkatkan jenjang 
karirnya dengan cara menjalankan tugasnya dengan baik, bisa mencapai target perusahaan dan pendidikan yang diampu oleh para karyawan.

Fasilitas yang mendukung kinerja karyawan di Bank BJB Syariah KCP. Kuningan yaitu mengenai sarana dan prasarana, jaminan kesehatan, pembagian insentif, kompensasi dan jenjang karir yang kurang memadai seperti akses internet yang sering mengalami gangguan, akses jaringan komuter yang ada sering mengalami kesalahan teknis, jenset yang disediakan kurang memadai, kurangnya inventaris kantor sehingga dapat menghambat kinerja para karyawan. Hal tersebut seharusnya tidak terjadi di dalam sebuah perusahaan, karena semua permasalahan tersebut dapat menghambat pekerjaan dan tujuan perusahaan. Sebuah perusahaan yang baik seharusnya menyediakan fasilitas yang dibutuhkan oleh para karyawan, dengan adanya fasilitas yang memadai akan menghasilkan kinerja karyawan yang baik dan produktif. Maka, dapat dikatakan bahwa pada kenyataanya fasilitas memiliki dampak terhadap kinerja karyawan di Bank BJB Syariah Kantor Cabang Pembantu Kuningan dan dengan adanya fasilitas yang disediakan oleh perusahaan akan meningkatkan kinerja karyawan yang lebih baik dan produktif sehingga Bank BJB Syariah dapat mencapai tujuan perusahaan.

\section{b. Sistem Kompensasi}

\section{Gaji}

Pemapaan yang disampaikan oleh karyawan, bahwa sistem atau proses pembagian gaji di Bank BJB Sariah Kantor Cabang Pembantu Kuningan menggunakan payrol, biasannya pembagian gaji dilakukan diakhir bulan setiap tanggal 25 tetapi jika tanggal 25 bertepatan di hari libur maka pembagian gaji akan dilakukan lebih cepat dari biasannya. Pimpinan bank juga menyampaikan, peraturan pemerintah dan peraturan perusahaan yang membahas mengenai mekanisme pembagian gaji dan upah, dalam peraturan tersebut tidak bertentangan dengan AlQuran dan Hadits.

\section{Tunjangan}

Tunjangan yang diberikan secara merata oleh Bank BJB Syariah Kantor Cabang Pembantu Kuningan kepada seluruh karyawan berupa tunjangan transportasi jika ada kegiatan di luar kota, tunjangan lembur, tunjangan kesehatan, tunjangan kesehatan untuk suami, istri dan satu orang anak. Tunjangan yang diberikan oleh perusahaan dinilai cukup dan sepadan dengan apa yang diharapkan dan dikerjakan oleh para karyawan di Bank BJB Syariah KCP. Kuningan. 
Dengan adanya tunjangan yang diterima, membuat karyawan semakin bersemangat untuk bekerja.

\section{Insentif dan Bonus}

Pemberian insentif dan bonus yang diberikan Bank BJB Syariah KCP. Kuningan kepada karyawan bisa berdampak baik terhadap kinerja karyawan, karyawan bisa lebih semangat dalam menjalankan pekerjaannya dan memperhatikan kualitas pekerjaan contohnya seperti, mencari nasabah sesuai dengan target lembaga, mencari pembiayaan, mempersiapkan proses pencairan dan pelepasan pembiayaan, melayani nasabah dengan baik sesuai dengan peraturan lembaga. Karyawan bisa mendapatkan insentif dan bonus jika mencapai target perusahaan.

\section{Fasilitas}

Fasilitas atau kebutuhan karyawan yang disediakan di Bank BJB Syariah KCP. Kuningan berupa uang makan siang, minuman dan makanan ringan, selain itu lingkungan kerja yang nyaman, kondusif, fasilitas yang memadai dan hubungan antara karyawan dengan pimpinan terjalin baik, sehingga memudahkan dalam bekerja secara tim.

Jadi, dapat dikatakan bahwa pada kenyataanya sistem kompensasi mempunyai dampak terhadap kinerja karyawan di Bank BJB Syariah Kantor Cabang Pembantu Kuningan dan dengan adanya sistem kompensasi yang disediakan oleh perusahaan akan meningkatkan motivasi, semangat kerja dan kinerja karyawan yang lebih baik dan produktif sehingga Bank BJB Syariah Kantor Cabang Pembantu Kuningan dapat mencapai tujuan perusahaan.

\section{c. Kinerja Karyawan}

\section{Kualitas dan Kuantitas}

Cara meningkatkan kualitas dan kuantitas kinerja karyawan di Bank BJB Syariah Kantor Cabang Pembantu Kuningan dengan memberikan bonus kepada karyawan ketika mencapai target, memberikan pelatihan kepada karyawan, memberikan kompensasi, menciptakan lingkungan kerja yang aman dan nyaman, menyediakan fasilitas sesuai dengan kebutuhan para karyawan, mampu menyelesaikan setiap pekerjaan sesuai dengan kapasitas masing-masing karyawan, memperbaiki dan menyelesaikan pekerjaan dengan baik.

\section{Ketepatan Waktu}


Manajemen waktu yang dilakukan para karyawan Bank BJB Syariah Kantor Cabang Pembantu Kuningan agar setiap pekerjaan senantiasa dapat terselesaikan dengan tepat waktu yaitu dengan cara, membagi waktu dengan baik, datang dan pulang sesuai dengan jam kerja yang sudah ditetapkan oleh perusahaan, mengerjakan pekerjaan dengan teliti, menyelesaikan pekerjaan yang paling penting, menyelesaikan lebih awal, tidak membuang waktu untuk hal yang tidak bermanfaat, jadikan pekerjaan sebagai sebuah kebiasaan, mengerjakan pekerjaan sesuai dengan tugas yang ada, menjalankan pekerjaan dengan baik dan sesuai dengan apa yang sudah diperintahkan perusahaan.

\section{Efektivitas}

Penggunaan sumber daya organisasi di Bank BJB Syariah KCP kuningan dapat dimaksimalkan dengan baik seperti memanfaatkan perangkat komputer dan internet sehingga kinerja karyawan lebih terbantu dan produktif.

\section{Kemandirian dan Komitmen}

Bentuk komitmen kerja antara karyawan dan intansi sudah di perjelas oleh visi dan misi perusahaan dan peraturan perusahaan. Sedangkan bentuk komitmen pada diri sendiri yaitu dengan cara menjalankan pekerjaan dengan baik dan benar yang sesuai dengan apa yang telah ditugaskan, menjalankan peraturan perusahaan dan peraturan pemerintah, datang tepat waktu, selalu berbicara dengan sopan dan baik, bangga terhadap pekerjaan yang sedang dijalankan, membina hubungan yang baik dengan para karyawan, loyal kepada perusahaan, memperbaiki kesalahan yang sudah terjadi. Dengan adanya komitmen antara karyawan dengan perusahaan akan menjadi motivasi serta memiliki rasa tanggung jawab untuk mengerjakan pekerjaan dengan baik.

Jadi, dapat dikatakan bahwa pada kenyataanya fasilitas dan sistem kompensasi dapat berdampak pada kinerja karyawan di Bank BJB Syariah KCP. Kuningan, karena secara teori menurut Mangkunegara (2009) bahwa faktor-faktor yang mempengaruhi kinerja terdiri dari faktor internal dan eksternal "faktor internal yaitu faktor yang dihubungkan dengan sifat-sifat seseorang. Sedangkan faktor eksternal adalah faktor-faktor yang mempengaruhi kinerja seseorang yang berasal dari lingkungan. Seperti prilaku, sikap dan tundakan-tindakan rekan kerja, bawahan atau pimpinan, fasilitas kerja, kompensasi dan iklim organisasi”.

\section{SIMPULAN}


Berdasarkan hasil penelitian bahwa Fasilitas yang disediakan oleh Bank BJB Syariah KCP. Kuningan belum terpenuhi dengan cukup baik, yaitu jaringan internet yang sering mengalami gangguan, kurangnya kendaraan operasional, lahan parkir yang kurang luas, sehingga mengganggu kinerja karyawan. Sedangkan untuk kompensasi, pihak lembaga sudah memberikan secara adil dan cukup baik sesuai dengan peraturan yang ada. Kedua hal tersebut tentunya memberikan dampak pada kinerja karyawan, sehingga dapat dikatan untuk failitas pihak Bank BJB Syariah KCP. Kuningan belum bisa memenuhi kebutuhan untuk meningkatkan kinerja para karyawan. Sedangkan untuk kompensasi yang telah diberikan oleh Bank BJB Syariah KCP. Kuningan sudah baik dan memberikan dampak pada kinerja para karyawan. Karyawan yang memiliki kinerja yang baik, akan berbanding lurus dengan hasilnya yang akan baik pula, begitupun sebaliknya karyawan yang memiliki kinerja yang buruk maka akan berdampak buruk pula pada perusahaan. Untuk menghasilkan karyawan dengan kinerja yang baik maka perusahaan harus selalu memperhatikan factor apa saja yang dapat mempengaruhi kinerja karyawan. Salah satu faktor yang dapat mempengaruhi kinerja karyawan yaitu fasilitas dan sistem kompensasi. Sehingga dalam sudut pandang ini Bank BJB Syariah Kantor Cabang Pembantu Kuningan belum bisa memenuhi kebutuhan untuk meningkatkan kinerja para karyawan yaitu pada aspek fasilitas.

\section{REFERENSI}

Ali, Muhammad Maulana. (1979). Qur'an Suci Teks Arab, Terjemaah Dan Tafsir Bahasa Indonesia, Terj. H. M. Bahrun. Jakarta. Darul Kutub Islamiah.

Audina Selda, Kurniati, Teguh Wicaksono. (2020). Analisis Sistem Kompensasi Dalam Meningkatkan Motivasi Kerja Karyawan PT. Kreasi Bangun Warna Banjarmasin. Universitas Islam Kalimantan.

Handani, Lupiyoadi.(2006). Manajemen Pemasaran Jasa, Jakarta. Selemba Embat.

Handoko T. Hani.(2001). Manaajemen Personalia Dan Sumber Daya Manusia. Yogyakarta.BPFE Yogyakarta.

Ibrahim. (2015). Metodologi Penelitian Kualitatif. Bandung. Alfabeta

Kasmir. (2016). Manajemen Sumber Daya Manusia. Jakarta. Rajawali Pers.

Lutfia, Anis. (2015). “Analisis Pengaruh Fasilitas, Gaji Serta Insentif Terhadap Produktivitas Kinerja Karyawan Warung Mikro Studi Kasus pada PT Bank Syariah Mandiri KCP Unggaran". Skripsi. Unggaran: IAIN Salatiga.

Lubis, Yusniar, Bambang Hermanto, Emron Edison. (2018). Manajemen dan Riset Sumber Daya Manusia. Bandung. Alfabeta.

Mangkunegara dan Anwar Prabu. (2009). Manajemen Sumber Daya Manusia Perusahaan. Bandung: PT Remaja Rosda Karya. 
Moekijat. (2001). Pengembangan Manajemen Dan Motivasi. Bandung. Pionir Jaya.

Nizam, Muhamad. (2018). Analisis Sistem Kompensasi Pada Pt. Bank Rakyat Indonesia Syariah Cabang Jelutung Kota Jambi. Universitas Islam Negri Sulthan Thaha Saifuddin.

Rivai, Vaithzal. (2004). Manajemen Sumber Daya Manusia Untuk Perusahaan Dari Teori Ke Praktik. Jakarta. Murai Kencana.

Sudarwan, Danim. (1995). Transpormasi Sumber Daya Manusia. Jakarta. Bumi Aksa. Sugiyono. (2017). Metode Penelitian Kombinasi (Mixed Methods). Bandung. Alfabeta

Sulastri, Lilis. (2010). Sumber Daya Manusia Strategik. Bandung. La Goods Publishing.

Sutrisno. Edy.(2009). Manajemen Sumber Daya Manusia. Jakarta. Kencana.

Syafri,Sofyan. (2001). Akuntansi Keprilakuan. Yogyakarta. Andi Offset.

Wirawan. (2015). Manajemen Sumber Daya Manusia Indonesia: Teori, Pisikologi, Hukum Ketenagakerjaan, Aplikasi dan Penelitian: Aplikasi Dalam Organisasi Bisnis. Pemerintahan dan Pendidikan. Jakarta. Rajawali.

Wibowo. (2012). Manajemen Kinerja, edisi ketiga. Jakarta. PT. Raja Grafindo Prasada. 